старовинному стилі»). Більшість п'єс циклу написано у мажорних ладах, що створює загальний позитивний настрій циклу в цілому.

Таким чином, твори для дітей М. Кармінського користується заслуженою любов'ю та популярністю у виконавців. У них органічно поєднуються інструктивні i художні задачі, образність змісту i досконалість засобів виразності. Дитячі п'єси М. Кармінського продуктивно впливають на загальний музичний розвиток дітей, виховують у них художнє мислення й смак, творчу уяву.

\title{
Література:
}

1. Воспоминания о Марке Карминском/ сост. Г. И. Ганзбург. Харьков : Каравелла, 2000. 132 с. : фот.

2. Кармінська I. М., Бахмет Т. Б. Кармінський Марко Веніамінович. Енциклопедія Сучасної України. Київ, 2012. Т. 12. С. 348 : фот.

3. Кармінський Марко Веніамінович. Мистецтво України: біогр. довід. / за ред. А. В. Кудрицького. Київ, 1997. С. 288.

DOI https://doi.org/10.30525/978-9934-26-004-9-135

\section{РИСИ ВИКОНАВСЬКОГО СТИЛЮ ФРЕНКА СІНАТРИ}

\author{
Чернова Р. O. \\ випускниия \\ Харківської державної академії культури \\ м. Харків, Украӥна
}

У 1920-х роках XX століття отримала своє розповсюдження манера естрадного співу «напівголосно» під назвою «крунінг». Згідно визначенню, наданому в Оксфордському словнику, крунінг являє собою «спів популярних пісень тихим, низьким, рівним голосом, близько тримаючи мікрофон» [5].

А. Р. Сраносов у праці «Традиційний джаз (від свінгу до сучасного мейнстриму)» зазначає, що «основоположником і майстром техніки “крунінг” є Бінг Кросбі. Можливість посилення звуку через мікрофон в корені змінила вокальні вимоги співаків 1920-х років. Класичні вокально-орієнтовані сценічні голоси були занадто гучними для нового середовища. Стримана, іноді безсила вокальна обробка ритмів і звуків $\epsilon$ найбільш істотною характеристикою крунінгу. Таким чином, пісні 
виконавців характеризуються низьким діапазоном i низькими динамічними коливаннями» [1].

Характерними особливостями манери «крунінг» $\epsilon$ наспівування, невимушене звуковидобування, подача матеріалу у формі оповідання, шляхетна простота, імітація розмови в паузах між куплетами, спокій, розслабленість, строгість і плавність виконання. Також основною стильовою ознакою можна виділити італійське бельканто, яке вимагає від співаків-крунерів бездоганної кантилени та майстерного філірування звуку, яке є невід ємною частиною джазового співу і полягає у зміні динаміки звучання взятої ноти від «ріапо» до «forte» або навпаки.

Френк Сінатра у своїй творчості прославився саме такою манерою виконання пісень і вважається найкращим співаком-крунером минулого століття. Сінатра володів виконавською манерою, яка зачаровувала. Хоча голос у нього був «невеликий» - «сухуватий» ліричний баритон, не багатий відтінками, проте, коли він співав на естраді, кожній дівчині 3 глядацького залу здавалося, що він співає лише для неї - м`яко і ніжно.

Голос Сінатри з часом ставав усе міцніше та поступово набував бархатистості звучання, спроможності поринати слухача у стан світлої меланхолії.

Особливу роль у виконанні пісень манерою «крунінг»є тембральна насиченість голосу. Тембр голосу Френка Сінатри отримав назву «оксамитового» баритону, який приголомшував публіку своєю легкістю, красою і глибиною звучання.

Спеціально для Френка Сінатри К. П. Дж. Мерсером було написано ряд композицій, зокрема: «Summer wind» (укр. «Літній вітер»), «One for my baby (and one more for the road)» (укр. «Одне для мого малюка (і ще одне для дороги)» [4, с. 314]. Ці пісні увійшли до першого сольного альбому Френка Сінатри, який отримав назву «Голос Френка Сінатри» (англ. «The Voice of Frank Sinatra», 1946). Саме в цих піснях Сінатра досяг емоційної глибини і музичної ясності, і вже тоді він став великим співаком, який професійно зростала впродовж 50-ти років своєї кар єри. Сама ж назва «The Voice» стала символічною.

За твердженням Джеймса Каплана, Френк Сінатра завжди співав під слоганом «Голос, який схвилював мільйони» [3, с. 501].

У 1942 році співака запросили заспівати на Різдвяному концерті у Нью-Йорку, в кінотеатрі «Раramount» (укр. «Парамаунт»), де його побачив агент Джордж Еванс, який зробив за два тижня виступів із Френка «зірку», улюбленця американських дівчаток-підлітків.

Джордж Еванс був доволі перебірливим стосовно того, кого він хоче представляти на сцені від свого імені. Стосовно Сінатри Еванс спочатку 
був скептично налаштований, незважаючи на хвалебний заклик Менні Сакс: «Але хлопчик - співак, він можливо навіть відрізняється від інших - від того, що ми чуємо у записах і радіо. У нього приємний i виразний голос» [3, с. 650]. Не дивлячись на це, Джордж Еванс не зовсім розумів про що йшла мова. «Тобі потрібно відвідати його, Джорджі», сказав Сакс, - у цієї людини дійсно щось є. Вирушай в Paramount i подивися, що він робить 3 цими дівчатами, з публікою» [3, с. 650]. «Еванс вирішив піти, подивитися на власні очі і послухати. Нелегко вражений, Еванс дивився на побачене. Місце було повністю заповнене істеричними дівчатами-підлітками, майже п`ять тисяч осіб. Вони гриміли на сидіннях, проходах, балконах і співає голодна на вигляд дитина в центрі уваги на центральній сцені. Коли Еванс ходив поруч зі сценою, 3 відкритим ротом: дівчина в кріслі біля проходу встала і кинула одну троянду з довгим стеблом, загорнутим в папір, співаку. Квітка на секунду затрималася у світлі променів від прожектора, після чого витонченим рухом Сінатра зловив іiі, усміхнувся їй і закрив очі, вдихаючи аромат ніжної квітки. В цей момент Джордж Еванс вирішив, що буде представляти Френка Сінатру. Він зупинився і уважно брав до уваги те, що він бачив, чув і відчував, але нічого подібного публіцист не бачив раніше. Іноді були дивні затишшя, а іноді натовп кричав, створюючи масивну стіну звуку, заважаючи Сінатрі робити те, що у нього виходило найкраще - співати. Еванс бачив, що зовнішня привабливість Френка Сінатри, хоча і була унікальною, проте була доволі обмеженою. Дівчатам був цей голос унікальною сумішшю особистості і безпосередньо голосу. Одні співаки славилися бездоганною зовнішністю, інші були видатними співаками, але ніхто не міг похизуватися симбіозом зовнішньої харизми та неймовірно унікального голосу, на відміну від Сінатри. Він “розповідав" пісню як ніхто інший, проживав іiі всім серцем, особливо, якщо пісня була баладою. Френк Сінатра сумував перед тисячами жінок, змушуючи кожну дівчину заплакати» [3, с. 650].

У той момент у Джорджа Еванса виникла ідея: «“Голос, який схвилював мільйони" - сила цього гасла змушувала його думати лише про те, що він міг би зробити набагато краще. Еванс закрив очі і подумав про те, що його вражає в цьому співаку - просто...голос. Миттєво впізнаваний, чаруючий, “оксамитовий” " [3, с. 655].

Успіх Френка Сінатри не був би таким значущим, якби він не знайшов оригінальну манеру музичного виконання. У 1950 році він втратив найдорожче, чим він володів - голос. «Я відкрив рот, а звідти вилетіла лише хмарка пилу» [2], - згадував співак. 
Не можна уникнути і не закцентувати своєї уваги саме на голосі Сінатри. «Оксамитовий» баритон - ніжний, зворушливий тембр, який змушує затамувати подих. Френк, не дивлячись на свій шалений успіх, розумів, що нема межі досконалості, тому завжди удосконалював свої вокальні дані. Улюбленим музичним інструментом Сінатри вважається тромбон, який вразив його своєю плавністю переходу одного звуку в інший. Саме так він дійшов висновку, якщо на таке неперевершене, наповнене глибиною звучання, здатний музичний інструмент, то людина без сумніву здатна відтворити подібне звучання своїм голосом. Так, співак розробив свою техніку дихання, яка згодом перетворилася на візитівку зіркового героя і прославила його на всю Америку, а згодом i на весь світ. Вмінню майстерно володіти своїм інструментом - голосом можна було тільки позаздрити, а жага до самовдосконалення була запорукою успіху.

\section{Література:}

1. Ераносов А. Р. Традиционный джаз (от свинга до современного мэйнстрима) : учеб. пособие. СПб. ; М. ; Краснодар : Лань : Планета музыки, 2011. 175 с. (Мир культуры, истории и философии).

2. Нёхофф, Эрик. История Френка : Copyright Librairie Arthème Fayard, 2003. Пер. С. Нечаев, 2005. URL: https://libking.ru/books/prose/prose-contemporary/161416-erik-nehoff-istoriya-frenka.html

3. Kaplan, James. «Frank The Voice», 2010. 786 p.

4. Meyer, Gerald. Frank Sinatra : The Popular Front and an American Icon. Science \& Society, Vol. 66, No. 3. 2002. P. 311-335.

5. Oxford Learner's Dictionaries. https://www.oxfordlearnersdictionaries.com/ 